\title{
Modified BG Prasad Socio-economic Classification, Updated - 2020
}

\section{Dhrubajyoti J Debnath ${ }^{1}$, Rakesh Kakkar ${ }^{2}$}

${ }^{1}$ Associate Professor, Department of Community and Family Medicine, All India Institute of Medical Sciences, Mangalagiri, Andhra Pradesh; ${ }^{2}$ Professor and Head, Department of Community and Family Medicine, All India Institute of Medical Sciences, Mangalagiri, Andhra Pradesh.

\begin{tabular}{|c|c|c|c|c|c|c|c|c|}
\hline Abstract & Introduction & Methodology & Results & Conclusion & References & Citation & \multicolumn{2}{|c|}{ Tables / Figures } \\
\hline \multicolumn{9}{|c|}{ Corresponding Author } \\
\hline \multicolumn{8}{|c|}{$\begin{array}{l}\text { Dr. Rakesh Kakkar, Professor and Head, Department of Community and Family Medicine, All India Institute } \\
\text { of Medical Sciences, Mangalagiri, Andhra Pradesh } \\
\text { E Mail ID: } \underline{\text { drrakesh75@rediffmail.com }}\end{array}$} & 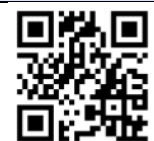 \\
\hline
\end{tabular}

\section{Citation}

Debnath DJ. Kakkar R. Modified BG Prasad Socio-economic Classification, Updated - 2020. Indian J Comm Health. 2020;32(1):124-125.

Source of Funding: Nil Conflict of Interest: None declared

\section{Article Cycle}

Received: 05/03/2020; Revision: 10/03/2020; Accepted: 21/03/2020; Published: 31/03/2020

This work is licensed under a Creative Commons Attribution 4.0 International License.

\section{Abstract}

SES of a family is often an important parameter of measurement in various health studies. Socioeconomic status is an important tool which influences the accessibility, affordability, acceptability, availability and utilization of various resources. The concept of socio-economic status is widely used in medical sociology.

\section{Keywords}

BG Prasad socio-economic status; Consumer Price Index CPI 2020

\section{Introduction}

Socio economic status (SES) is one of the prime factors influencing the health status of a nation. (1) SES of a family is often an important parameter of measurement in various health studies. Socioeconomic status is an important tool which influences the accessibility, affordability, acceptability, availability and utilization of various resources. The concept of socio-economic status is widely used in medical sociology. This is an important parameter affecting the health condition of an individual, family, social security system. Social class also influences the ability to identify the emotions of others (i.e., emotion perception). $(2,3,4)$ SES also guide appropriate economic and public health policies. (5)

There are several scales to measure socio-economic status in India. The modified Kuppuswamy scale has combined education, occupation of the head of the family, and income per month of the family from all sources. Pareekh SES had added caste and family type with a total of nine indicators. In Gour's classification, expenditure was combined with income, education, occupation, and living standard. Tiwari SES used seven profiles i.e. housing, material possession, education, occupation, economic profile, cultivated land, and social profile in his scale. $(6,7)$ Modified BG Prasad's classification is used for both urban and rural areas. An update of Prasad's socio-economic classification (1961) of Indian population has been proposed with relevance to the current consumer index price levels of January 2020. $(8,9,10)$

Modified BG Prasad scale is the one of the most widely used scale to measure the socioeconomic status of families. (11) B G Prasad's classification was based on per capita monthly income and the scale evolved in 1961. This was later modified in 1968 and 1970. (10,11,12) BG Prasad's classification was introduced considering the base of Consumer Price Index (CPI) for 1960 as 100 (10) modified in 1982 and 2001 by introducing linking factors to convert CPI (1982 and 2001) from the new base of 100 to the old base CPI (1960). (Table 1) The linking factors for 1982 and 2001 were 4.93 and 4.63, respectively. (8) All India average Consumer Price index (for Industrial workers) for January 2020 (on Base 2001=100) $=330$. (13) Multiplication factor $=$ Current index value $(330) /$ Base index value in $2001(100)=3.3$. Therefore, New income value $=$ multiplication factor $\times$ old income value $\times 4.63 \times$ 4.93. The updated values for the per capita monthly income (in Rs./month) for Jan 2020 are given in (Table 2)

\section{Conclusion}

Due to inflation, over a period of time there are changes in the Consumer price index in the country which makes it very essential to periodically update the socio-economic 
INDIAN JOURNAL OF COMMUNITY HEALTH / VOL 32 / ISSUE NO 01 / JAN - MAR 2020 scales based on income. In this article, the B G Prasad SES has been updated with the latest All India average Consumer Price index January 2020. This updated B G Prasad scale will be helpful for researchers using SES as one of the study variables.

\section{References}

1. Wani RT. Socioeconomic status scales-modified Kuppuswamy and Udai Pareekh's scale updated for 2019. J Family Med Prim Care. 2019 Jun;8(6):1846-1849. doi: 10.4103/jfmpc.jfmpc_288_19. PMID: 31334143; PMCID: PMC6618222.

2. Manstead ASR. The psychology of social class: How socioeconomic status impacts thought, feelings, and behaviour. Br J Soc Psychol. 2018 Apr;57(2):267-291. doi: 10.1111/bjso.12251. Epub 2018 Feb 28. PMID: 29492984; PMCID: PMC5901394.

3. Deveney CM, Chen SH, Wilmer JB, Zhao V, Schmidt HB, Germine L. How generalizable is the inverse relationship between social class and emotion perception? PLoS One. 2018 Oct 19;13(10):e0205949. doi: 10.1371/journal.pone.0205949. PMID: 30339671; PMCID: PMC6195285.

4. Sharma R. Revised Kuppuswamy's Socioeconomic Status Scale: Explained and Updated. Indian Pediatr. 2017 Oct 15;54(10):867870.

5. Kattula D, Venugopal S, Velusamy V, Sarkar R, Jiang V, S MG, Henry A, Deosaran JD, Muliyil J, Kang G. Measuring Poverty in Southern India: A Comparison of Socio-Economic Scales Evaluated against Childhood Stunting. PLoS One. 2016 Aug 4;11(8):e0160706. doi:
[BG Prasad SES...] | Debnath DJ et al 10.1371/journal.pone.0160706. PMID: 27490200; PMCID: PMC4973914.

6. Oberoi SS. Updating income ranges for Kuppuswamy's socioeconomic status scale for the year 2014. Indian J Public Health 2015;59:156-7.

7. Saif-Ur-Rahman KM, Anwar I, Hasan $M$, Hossain $S$, Shafique $S$, Haseen F, Khalequzzaman M, Rahman A, Islam S. Use of indices to measure socio-economic status (SES) in South-Asian urban health studies: a scoping review. Syst Rev. 2018 Nov 17;7(1):196. doi: 10.1186/s13643-018-0867-6. PMID: 30447696; PMCID: PMC6240202.

8. Pandey VK, Aggarwal P, Kakkar R. Modified BG Prasad Socioeconomic Classification, Update - 2019.Indian J Comm Health. 2019; 31, 1: 123-125.

9. Sharma R. Revision of Prasad's social classification and provision of an online tool for real-time updating. South Asian J Cancer. 2013 Jul;2(3):157. doi: 10.4103/2278- 330X.114142. PubMed PMID: 24455606; PubMed Central PMCID: PMC3892518.

10. Prasad BG. Social classification of Indian families. J Indian Med Assoc 1961;37:250-1.

11. Prasad BG. Social classification of Indian families. J Indian Med Assoc. 1968;51:365-6.

12. Prasad BG. Changes proposed in social classification of Indian families. J Indian Med Assoc. 1970;55:198-9.

13. Press Release. Consumer Price Index Numbers for Industrial Workers on Base 2001=100. Available from: http://labourbureau.gov.in/LBO_Press_Release.htm. Accessed on 4th April 2020.

\section{Tables}

TABLE 1 REVISED PER CAPITA INCOME PER MONTH LIMITS

\begin{tabular}{|c|c|c|c|c|}
\hline $\begin{array}{l}\text { Price index by Old } \\
\text { base (1960) for the } \\
\text { original scale }\end{array}$ & $\begin{array}{l}\text { Price index by new } \\
\text { base (1982) for the } \\
\text { year } 1982\end{array}$ & $\begin{array}{l}\text { Linking factor } \\
\text { between } 1960 \text { and } \\
1982 \text { series }\end{array}$ & $\begin{array}{l}\text { Price index by new } \\
\text { base }(2001) \text { for the } \\
\text { year } 2001\end{array}$ & $\begin{array}{l}\text { Linking factor } \\
\text { between } 1982 \text { and } \\
2001 \text { series }\end{array}$ \\
\hline 100 & 100 & 4.63 & 100 & 4.93 \\
\hline
\end{tabular}

TABLE 2 PROPOSED MODIFIED BG PRASAD'S SOCIAL CLASSIFICATION

\begin{tabular}{|c|c|c|c|}
\hline \multicolumn{2}{|c|}{ Prasad's social classification (1961) } & \multicolumn{2}{|c|}{ Revision of the Prasad's social classification for the year 2020} \\
\hline \multirow[t]{2}{*}{ Social Class } & \multirow[t]{2}{*}{ Per capita monthly income limits } & \multirow[t]{2}{*}{ Social Class } & Revised for 2020 \\
\hline & & & (in Rs./month) \\
\hline I & 100 and above & 1 & 7533 and above \\
\hline II & $50-99$ & II & $3766-7532$ \\
\hline III & $30-49$ & III & $2260-3765$ \\
\hline IV & $15-29$ & IV & $1130-2259$ \\
\hline V & Below 15 & $\mathrm{~V}$ & 1129 and Below \\
\hline
\end{tabular}

